\title{
Isomorphism, Institutionalization and Legitimacy: Operational Auditing at the Court of Auditors
}

\author{
Carlos Alberto Sampaio de Freitas \\ Tomás de Aquino Guimarães
}

\section{ResUMo}

Este trabalho objetiva verificar qual a relação entre o conceito de legitimidade e o fenômeno de institucionalização da atividade de auditoria operacional no Tribunal de Contas da União em um contexto de isomorfismo institucional. Foi realizado exame documental abrangendo o período de 1987 a 2004 e entrevistas com 18 pessoas envolvidas na referida atividade no TCU. Os resultados sugerem que existe relação entre isomorfismo e legitimidade, entretanto apenas no que se refere a um tipo de legitimidade. O fenômeno do isomorfismo atua no sentido de conferir legitimidade cognitiva, enquanto que atuam outros fatores, ligados a cultura e ao ambiente institucional do país, que interferem na dimensão da legitimidade moral, resultando na institucionalização da atividade em um nível secundário na organização analisada. Por fim, observou-se que o processo de instituticionalização, no caso presente, apresenta característica circular, no qual as fases de inovação, difusão, saturação parcial e desinstitucionalização parcial se sucedem de forma cíclica, modificando a atividade de auditoria operacional ao longo do tempo no TCU.

Palavras-chave: institucionalização; isomorfismo; legitimidade; auditoria operacional.

\begin{abstract}
The aim of this paper is to verify the nature of the relationship between the concept of legitimacy and the phenomenon of institutionalization of operational auditing at the Court of Auditors in a context of institutional isomorphism. A documental examination was conducted covering the period of 1987 to 2004 and 18 people involved in the aforementioned activity at the Court of Auditors were interviewed. The results suggest that there is a relationship between isomorphism and legitimacy but only concerning one type of legitimacy. The phenomenon of isomorphism acts in the sense of checking cognitive legitimacy while other factors are at work which are connected to the culture and institutional environment of the country, which interfere in the dimension of moral legitimacy, resulting in institutionalization of the activity at a secondary level in the analyzed organization. It was seen that the process of institutionalization, in this case, has a circular characteristic, in which the phases of innovation, diffusion, partial saturation and partial deinstitutionalization follow one another cyclically, modifying the activity of operational auditing over time at the Court of Auditors.
\end{abstract}

Key words: institutionalization; isomorphism; legitimacy; operational auditing. 


\section{INTRODUCTION}

This paper aims to verify the relationship between the concept of legitimacy and the phenomenon of institutionalization in the operational auditing at the Court of Auditors (COA). The Court, a higher inspection body in Brazil, introduced operational auditing in the early 1980s, adopting a series of initiatives over the years for its development. However, no systematic studies have been carried out on how and why the process was begun and developed and which factors account for its persistence. This paper seeks to contribute towards filling these gaps of knowledge, analyzing, from the trajectory of the beginning, implantation and development of operational auditing at the COA, which the link is between the concept of legitimacy and the phenomenon of institutionalization of this activity. To this end, we seek a theoretical base in the institutional approach to explain the institutionalization of the activity and its legitimacy and understand the influence of the phenomenon of institutional isomorphism in the process.

Higher Inspection Bodies (HIB) are governmental organizations, generally connected to the Legislature of different countries who are given the task of helping Parliament control public administration. They carry out their duties by adopting basically two different models: a) Court of Auditors, predominant in Latin countries (France, Italy, Spain, Portugal, Brazil); b) Controller General of Finances, found in Anglo-Saxon countries and most of Latin America. The focus of the work of HIBs is also basically divided in two: a) administrative actions conforming to the law, norms and regulations and combating the misuse of public resources; b) results of governmental action.

These organizations basically utilize three modalities of auditing in the course of their duties: operational, financial accounting and legality. Operational auditing aims to analyze the performance of operations, information and organization systems, administration methods and administrative policies (Araújo, 2001), whereas financial accounting auditing analyzes the suitability of the accounts and finances of organizations and conformity auditing seeks to verify that legislation has been followed by the audited organization along with the existence and workings of internal controls, probity and propriety of the acts of the managers (Intosai, 1995).

Operational auditing, developed initially in Anglo-Saxon countries that adopt the controller general model has been found to be on the rise among HIBs (Londsdale, 2000). This expansion suggests the existence of an isomorphic phenomenon, which 
is, according to DiMaggio and Powell (1991), the homogenization of practices, processes and structures on the part of organizations operating within the same organizational field.

\section{InSTITUTION, INSTITUTIONALIZATION, LEGITIMACY AND ISOMORPHISM}

Scott (1995) defines institution as a cognitive, normative or regulatory structure or activity that provides stability and meaning for social behavior. According to this author, institutions are transported by several vehicles such as cultures, structures and routines, which operate at multiple levels of jurisdiction. Meanwhile Jepperson (1991) defines institution as an organized and established procedure in the form of a constituted normative system of self-reproduced, socially constructed routines. While institution represents a social order or pattern which has reached a certain state or propriety, institutional denotes the process which leads to this state (Jepperson, 1991).

Berger and Luckman (2003, p. 79) consider the phenomenon of institutionalization to occur "whenever there is reciprocal typification of habitual actions by types of actors". A set of habitual actions, whose formation process precedes institutionalization is attributed over time (historicity) and in a shared manner, to a certain actor or actors who begin to perform roles in the social context (Berger \& Luckman, 2003).

Zucker (1991) understands institutionalization as a process by which individual actors transmit what is socially defined as real and, at the same time, as a variable of how much an action can be considered right in a given social reality. This author also defends the position that generally the institutionalization process occurs as a sub-product of the creation of other structures, but that once institutionalized, the structure or activity is maintained without any need for further actions. Powell (1991) holds the belief that institutionalization is a compulsory process that forces units of a population to become assimilated to other units who are facing the same challenges, an idea that will be explored under the denomination of isomorphism.

According to Jepperson (1991), a possible metric of the degree of institutionalization of an object concerns its vulnerability to social intervention. Thus, an institution is less vulnerable to intervention if it is rooted in a structure of organizations. This author also believes that the more an institution is seen as natural (considered right) or not subjected to questioning, the higher its degree of institutionalization. 
Examining the temporal characteristics of the phenomenon of institutionalization, Lawrence, Winn and Jennings (2001) point to a typical pattern of events and relations in an institutionalization process, shown in Figure 1: (1) initial phase of innovation involving few actors; (2) phase of rapid diffusion; (3) saturation and complete legitimization stage and (4) deinstitutionalization phase.

\section{Figure 1: Traditional Institutionalization Curve}

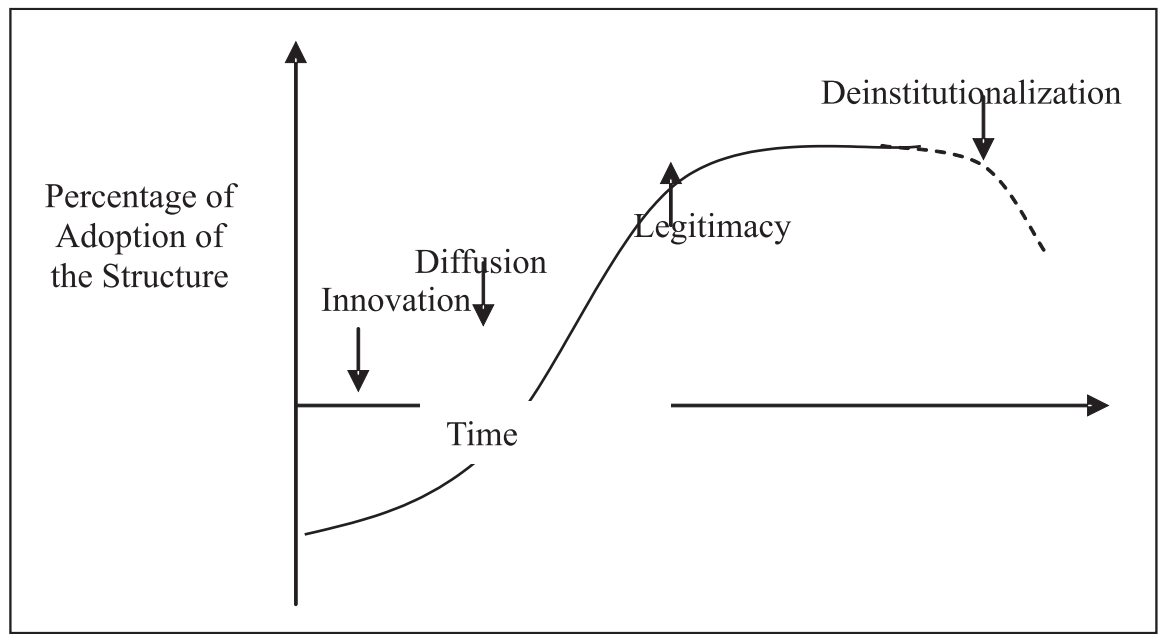

Source: Lawrence and Jennings (2001).

From the phenomenological line of Berger and Luckman (2003, p. 79), who understand institutionalization as a "reciprocal typification of habitual actions by types of actors", fundamental to the creation and perpetuation of any institutional order (group, activity, etc.), Tolbert and Zucker (1997) structure an institutionalization model in three stages (pre-institutional, semi-institutional and full institutionalization) characterized by sequential processes (habitualization, objectification and sedimentation) as seen in Table 1. 


\section{Table 1: Stages and Processes of Institutionalization}

\begin{tabular}{|l|l|l|}
\hline \multicolumn{1}{|c|}{ Stage } & \multicolumn{1}{|c|}{ Process } & \multicolumn{1}{c|}{ Description } \\
\hline Pre-institutional & Habitualization & $\begin{array}{l}\text { Includes the innovations and changes made in response to } \\
\text { specific organizational problems that results in structures } \\
\text { at the pre-institutionalization stage, limited in terms of } \\
\text { operation and, generally, not permanent. Takes into } \\
\text { consideration the solutions adopted in other organizations } \\
\text { with the possibility of the occurrence of mimetism. }\end{array}$ \\
\hline Semi-institutional & Objectification & $\begin{array}{l}\text { Consists of the development of social consensus between } \\
\text { decision makers in the organization on the value of the } \\
\text { structure from obtaining and analyzing information and } \\
\text { its dissemination in other organizations of the same field } \\
\text { (interorganizational monitoring), implying the diffusion } \\
\text { of the structure. At this stage, the leaders (defenders of } \\
\text { change) play an important role, carrying out the tasks of } \\
\text { theorizing that aim to attribute general cognitive and } \\
\text { normative legitimacy. }\end{array}$ \\
\hline Full institutionalization & Sedimentation & $\begin{array}{l}\text { Is characterized by the virtually complete propagation of } \\
\text { its structures for th e whole group of theorized actors as } \\
\text { suitable adopters and the perpetuation of structures for a } \\
\text { considerably long period of time. }\end{array}$ \\
\hline
\end{tabular}

Source: prepared from Tolbert and Zucker (1997).

A factor that is closely linked to institutionalization is legitimacy, which constitutes "a generalized perception or supposition that actions of an entity are desired, their own or suitable within some system of norms, values, beliefs and socially constructed definitions" (Suchman, 1995, p. 4). According to this author, legitimacy would play a central role in the intellectual transformation made possible by the institutional theory, providing the basis for a framework of theoretical formulations surrounding normative and cognitive forces that construct, limit and strengthen organizational actors. Thus, legitimacy and institutionalization would be virtually synonymous (Suchman, 1995).

According to Scott (2001), legitimacy was primarily recognized as being centrally important in social life by Weber, who identified its sources in tradition, charisma and rational-legal devices. Also according to Scott (2001), Parsons and, more recently, Pfeffer reaffirmed the idea of legitimacy and adaptation of organizational goals to social values. In the search for legitimacy and social acceptance, organizations seek to make their actions, structures and practices become closer to the patterns held to be socially correct (Scott, 1991). This conformity, for organizations, would be more efficient in the sense of guaranteeing their survival through improvement and recognition by society than performance itself, the reason why it is utilized in turbulent and risky times (Meyer \& Rowan, 1991; Machadoda-Silva, 1993).

Pfeffer and Salancik (1978) highlight that organizations consume resources of society, which, in their turn, assess the usefulness and legitimacy of their activities. 
Also according to these authors, legitimacy is a status conferred to the organization when the stakeholders endorse and support its goals and activities. According to Jepperson (1991), legitimacy is a product of institutionalization or contributes to it, but not always is it connected to it, seeing that illegal elements may be institutionalized such as corruption, fraud and organized crime.

Suchman (1995) proposes the following typology concerning the concept of legitimacy: pragmatic legitimacy, moral legitimacy and cognitive legitimacy. According to him, all three types involve a generalized perception that the activities of the organization are desirable or appropriate within a socially constructed system of norms, values, beliefs and definitions, each one differentiated by its dynamic behavior, as shown in Table 2 .

\section{Table 2: Types of Legitimacy}

\begin{tabular}{|l|l|l|}
\hline \multicolumn{1}{|c|}{ Pragmatic } & \multicolumn{1}{c|}{ Types of Legitimacy } & \multicolumn{1}{c|}{ Moral } \\
\hline $\begin{array}{l}\text { Based on the calculation of } \\
\text { interests of actors who are more } \\
\text { closely linked to the organization. }\end{array}$ & $\begin{array}{l}\text { Reflects a positive assessment of } \\
\text { the organization and its activities, } \\
\text { based on socially constructed } \\
\text { values. }\end{array}$ & $\begin{array}{l}\text { Consists of the acceptance of the } \\
\text { organization as necessary or } \\
\text { inevitable from the point of view of } \\
\text { a determined cultural framework. } \\
\text { The existence of the organization is } \\
\text { taken for granted, which means } \\
\text { that the actors no longer imagine } \\
\text { its non-existence. }\end{array}$ \\
\hline
\end{tabular}

Source: Prepared from Suchman (1995).

Also according to Suchman (1995), the three types of legitimacy co-exist in most of scenarios and are interrelated. As it moves from pragmatic to cognitive, passing the moral, legitimacy becomes more difficult to obtain and manipulate because the latter two factors depend on a more consistent cultural framework. In some cases, these types are reinforce each other while in others they come into conflict with each other.

Another concept to be approached for the comprehension of the process of introducing and developing operational auditing into the Court of Auditors is isomorphism, understood as the search for homogeneity of structures, processes and actions in an organization. Scott (2001) reminds us that the principle of isomorphism was utilized for the first time in organizational ecology in the late 1960s. In effect, for organizational ecology, isomorphism is the result of the competitive pressures that force organizations to adopt a form that is more suitable to their survival (Hannan \& Freeman, 1977).

According to DiMaggio and Powell (1991), the environment is a factor of organizational homogenization in that they are diffused practices and forms of 
organization that are institutionalized by the community of organizations belonging to the same field. The phenomenon of homogenization itself, which is denominated isomorphism, may be given because of its different causes, being developed, according to DiMaggio and Powell (1991), through three different mechanisms: coercive, normative and mimetic.

Coercive isomorphism takes place when organizations are submitted to external pressures, formal or informal, originating from other organizations of which they are dependent or owing to the cultural expectations of the society in which the organization is inserted. The best known example of this mechanism is the action of the government on organizations, through laws, norms and demands concerning production patterns, organizational behavior and relationships with consumers. Normative isomorphism stems directly from the establishment of patterns by a determined professional community with a view to cognitively founding and giving legitimacy to its developed activity. Universities and professional associations are two important sources of isomorphism in this perspective. Finally, mimetic isomorphism occurs in times of uncertainty, which compels organizations to seek structuration patterns and actions from other organizations. When seeing the success of other organizations in the same business, organizations tend to display mimetic behavior, which explains the existence of uniformity in the business world (Machado-da-Silva, Fonseca, \& Fernandes, 2000; Pacheco, 2002).

According to Machado-da-Silva et al. (2000) the weight of each of these three isomorphic mechanisms on processes of organizational transformation depends on the situation and socio-cultural history of each society. Thus it is in democratic societies and societies with greater competitive supply of goods and services mimetic and normative processes tend to be predominant while in societies with a tradition of auditing, such as Brazil, there is a tendency for coercive mechanisms to be predominant. In the specific case of Brazilian society, formalism, discrepancy between the content of norms and social reality would be linked to the coercive mechanisms in the dynamic of social changes (Machado-da-Silva, Guarido Filho, Nascimento, \& Oliveira, 2003).

\section{Methods and Procedures}

This study, carried out in the second half of 2004, is exploratory and of a qualitative nature, seeking to offer detailed descriptions of the phenomenon under study (Patton, 1990; Vieira, 2004). The analysis level is organizational (Scott, 1994) as the implantation of an activity in a determined organization was studied. The methodological strategy chosen is the case study of Yin (2001). 
A documental study was made of the period ranging from 1987 to 2004, with the following documents being consulted: Federal Information Sheet, Court of Auditors Journal, Minutes and Documents of the Technical Cooperation Project - United Kingdom and Control Paradigms Report concerning the Tendencies of Control Study carried out by the COA in 1999 and 2000. The information obtained in the documental examination was synthesized into analytical sets. Eighteen semistructured interviews were also held with the use of a script prepared using the theoretical framework. The interviewees were selected according to information obtained from the documental examination, informal conversations with members of the organization and recommendations from other interviewees. The interviews were edited and analyzed to seek convergences, divergences and emerging issues, to compare and contrast the findings with the theoretical framework.

To deepen the analysis of the interviews, Atlas.TI Software (version 5.0) was used, which helped to identify analysis categories. Each interview was submitted to a codification process of stretched of interview that were grouped into families of codes corresponding to the variables of research. Each family of codes (variable) was analyzed, preliminarily considering the quantification of codes that make it up and, later, the qualitative content of the stretches, seeking, when possible, to identify the relationship networks that were registered in diagrams constructed with the help of the Atlas.TI.

For the purposes of analysis, the acts of the COA pertaining to operational auditing were divided into three periods: (1) 1987-1992, (2) 1993-1998 and (3) 1999-2004, whose limits include events or observed significant tendencies. The first period ranges from the embryonic initiatives of introduction of the activity, the inclusion in the Federal Constitution of 1988, of the competence of the Court to carry out operational inspections and an initial effort to diffuse this type of work to all the COA. The second period begins with a decline in the activity and ends with an effort to revitalize it, this time centered on Government Programs. The third period begins with the beginning of the Technical Cooperation Project with the United Kingdom, which contributes towards the development of the activity of operational auditing.

\section{Legitimacy of Operational Auditing at the Court of Auditors}

\section{7 to 1992}

Although the Court of Auditors had participated in debates on operational auditing at international congresses of HIBs in the 1970s, the first evidence of 
operational auditing at the COA was seen in the publication of law 199 in 1982 which approved instructions for the implantation of a modality of auditing that had been called programmatic and whose goals were close to the concept of operational auditing.

Later, through another normative act, law 195 of 24/09/1984, the COA also approved, provisionally, instructions on another modality, denominated economic and efficient auditing, also known as operational auditing. After 28 tasks of economy and efficiency, in 1987 the Court, through a Plenary Decision (Annex VI of Act 46/1987) recognized the importance of operational auditing as a control activity and set the adoption of measures to implant it.

In 1988, the Federal Constitution attributed expressly to the COA the competence to carry out operational auditing in Article 70:

Article 70. Inspection of accounting, finances, budgeting, which is operational and patrimonial of the Federal Government and its direct and indirect administration bodies, pertaining to legality, legitimacy, economics, application of subventions and renouncement of receipts, will be exercised by the National Congress through the external control and by the system of internal control of each power (the emphasis is that of the authors).

In 1989, the COA began to do operational auditing with the First Plan for Operational Auditing at 35 Indirect Administration bodies. Some tasks began to be carried out and the COA Commission was created to study and provide ways to do the activity, mainly concerning training. In 1990, the first technical norm specifically mentioning operational auditing, beginning with a training course that would reach all the technical units of the Court by 1991 at the same time in which several auditing tasks of the modality were carried out by 1992.

From the analysis of the tests published in the COA Journal and in the Government Information Sheet at the time, evidence was found of three types of legitimacy shown by Suchman (1995) as shown in Table 3. We can see that the predominant arguments are those pertaining to cognitive legitimacy, with 18 citations, followed by arguments concerning moral legitimacy with 13 citations and, finally, arguments concerning pragmatic legitimacy with eight citations. 


\section{Table 3: Arguments of Legitimacy of Operational Auditing at the COA Identified in Documental Analysis for 1987 to 1992}

\begin{tabular}{|l|l|c|}
\hline Type of Legitimacy & \multicolumn{1}{|c|}{ Arguments } & No. of Citations \\
\hline \multirow{3}{*}{ Cognitive } & Mimetic Isomorphism & 9 \\
\cline { 2 - 3 } & Coercive Isomorphism (Federal Constitution) & 9 \\
\cline { 2 - 3 } & Total & $\mathbf{1 8}$ \\
\hline \multirow{4}{*}{ Moral } & Conformity versus Results & 7 \\
\cline { 2 - 3 } & Modern Technique & 4 \\
\cline { 2 - 3 } & Recommendations versus Decisions & $\mathbf{1 3}$ \\
\cline { 2 - 3 } & Total & 8 \\
\hline \multirow{2}{*}{ Pragmatic } & External Recognition & $\mathbf{8}$ \\
\cline { 2 - 3 } & Total & \\
\hline
\end{tabular}

Source: research data.

As for Cognitive Legitimacy, we see from the content of texts and speeches a concern with presenting operational auditing as a universally adopted practice by the other HIBs in the world. In this sense, in addition to the dissatisfaction with the way the control of legality was done, we saw that the actions of mechanisms of mimetic isomorphism in the introduction of the activity, since the other HIBs already had operational auditing on a routine basis.

Still on the subject of Cognitive Legitimacy, the Federal Constitution argument calls attention to the introduction of the attribution, to the COA, to carry out operational auditing in the Constitution of 1988 and for the need or even the inevitability to meet the requirements of the constitution. The content of the interviews confirms the idea that the introduction of a constitutional article was fundamental to the development and continuity of the work of operational auditing and this article, explicitly, conferred the legal competence to the COA to carry out this type of work.

The constitutional attribution served, for the external legitimacy process of the inspected entities, who could not argue lack of competence of the COA, and for the internal legitimacy process, with the argument that "it is written in the Constitution and must be done". We can infer, although no documental evidence has been found, that the Court itself participated actively in the insertion of the issue in the Federal Constitution. From the early 1980s, the subject was a talking point at the COA, which had already run a pilot scheme of operational auditing. From what we can see, the Court contributed to inserting the subject into the Constitution, which was accepted by the National Constitution Assembly.

Here we can see an interesting fact: a phenomenon of mimetic isomorphism acting to establish coercive isomorphism. This strengthens the importance of the coercive mechanisms in Brazilian society shown by Machado-da-Silva et al. (2003). The COA, by seeking the behavior patterns of other HIBs, not only implanted the 
activity of operational auditing into its routines, but also contributed to the other courts of auditors in the states, in a certain way compelled them, to become involved in the activity in question as the state constitutions tend to be very similar to the Federal Constitution.

On the subject of Moral Legitimacy, the argument of conformity versus results is predominant, with seven citations in that the analysis of conformity or legality is not enough for the whole exercise of control of public expenditure and it is necessary to complement it with the analysis of results of governmental action. Operational auditing, according to the arguments contained in the Modern Technique code would consist of a new tool that would meet this need to assess the results. The content of the interviews confirms this, and we see that from the point of view of the interviewees, one of the motives to introduce operational auditing in the Court was dissatisfaction with the control model of legality, until then the only one in force.

Concerning Pragmatic Legitimacy, the argument of external recognition refers to favorable manifestations of authorities on auditing carried to at PROÁLCOOL, Açominas and Embrapa, with four of the eight manifestations being made to the latter. In effect, the work of operational auditing done at Embrapa in the early 1990s was cited as an activity at the COA.

Embrapa was going through a difficult time and there was talk that it would be closed down. The work of the Court attracted attention to the importance of research into agriculture and livestock in the country and had wide repercussion in the media and in political circles. The organization was not closed down, although we cannot affirm that the work of the COA was the determining factor in this case. What can be said is that the report was very well received at the company, becoming a source of pragmatic legitimacy in relation to the audited organization and, at the same time, the object of internal criticisms concerning the actions of the COA, in that it could not carry out this work to help a specific organization. Nevertheless, it has to be said that no evidence was ever found of any deliberate intention to help Embrapa. No matter, it was seen that owing to the controversy, there was a conflict between arguments pertaining to the field of pragmatic legitimacy and moral legitimacy.

During this initial period, there was a significant quantity of norms published concerning operational auditing which acted as a source of legitimacy. This predominance of norms suggests the incidence of the phenomenon of formalism in the introduction of operational auditing. Formalism, whose importance in Brazilian society is discussed by Machado-da-Silva et al. (2003) is shown in this case since the norms preceded the collective customs and practices of operational auditing at the Court. There were cases of operational auditing that was typically 
a front since they were carried out with the auditing techniques of conformity. Nevertheless, the later development of the activity distanced the characteristic of formalism as they organization did not adopt a provisional solution and there was an effective effort to adopt the new auditing modality.

In relation to the other courts of auditors of the states, which also acquired these duties through State Constitutions, however, there are indications of the occurrence and persistence of formalism, considering that, according to Barros (1999) many did not succeed in implanting the activity of operational auditing.

\section{3-1998}

From the mid nineteen nineties, operational auditing was revitalized at the Court. First, in 1996, by a project of Capacity in the Assessment of Government programs based on the experience of the United States and, later, in 1998, by a Project of Technical Cooperation with a body of the British Government, which conferred a new influx of cognitive legitimacy to the activity, this time focused on the assessment of public programs. The quantification of the citations in the texts and discourses analyzed shows that, over the period, there were 23 citations for Moral Legitimacy, followed by Cognitive Legitimacy with 15 citations, while Pragmatic Legitimacy did not have a significant expression during this period, with only one citation (Table 4).

\section{Table 4: Arguments of Legitimacy of Operational Auditing at the COA Identified in Documental Analysis from 1993 to 1998}

\begin{tabular}{|l|l|c|}
\hline \multicolumn{1}{|c|}{ Type of legitimacy } & \multicolumn{1}{|c|}{ Arguments } & No. of citations \\
\hline \multirow{4}{*}{ Moral } & Conformity versus Results & 16 \\
\cline { 2 - 3 } & Modern Technique & 3 \\
\cline { 2 - 3 } & Task Results & 4 \\
\cline { 2 - 3 } & Total & $\mathbf{2 3}$ \\
\hline \multirow{3}{*}{ Cognitive } & Mimetic Isomorphism & 8 \\
\cline { 2 - 3 } & Coercive Isomorphism (Federal Constitution) & $\mathbf{1 5}$ \\
\cline { 2 - 3 } & Total & 1 \\
\hline Pragmatic & External recognition & $\mathbf{1}$ \\
\cline { 2 - 3 } & Total & \\
\hline
\end{tabular}

Source: research data.

Moral Legitimacy, a predominant typology of the period materialized mainly in the argument of Conformity versus Results, found often in the discourse of the COA President from 1995 to 1996, stating that it would not be admissible the COA to be concerned only with the irregularities found in Public Administration without also dealing with the waste resulting from the lack of concern with the results of government action. 
When it comes to Cognitive Legitimacy, the argument for Mimetic Isomorphism seeks to attract attention to the fact that Higher Inspection Bodies worldwide are concerned with the analysis of the results of government action, especially with the evaluation of government programs. In turn, the Federal Constitution seeks to emphasize that the constitutional attribution of the COA is clear for handling inspections of an operational nature, among them the evaluation of public programs.

\section{9-2004}

An increase in the degree of legitimacy with the establishment of links with the Government of the United Kingdom and with a flow of financial resources from that country led to an increase in the number of operational audits carried out by the Court from 1999 to 2004. Furthermore, during that time, another specific organizational unit at the COA to carry out program evaluations with a focus on operational auditing was created. The documental analysis shows, at the time, that Moral Legitimacy had the highest number of citations (45), followed by Cognitive Legitimacy, with 16 citations and Pragmatic Legitimacy with nine citations, as shown in Table 5.

Table 5: Arguments of Legitimacy of Operational Auditing at the COA Identified in Documental Analysis from 1999 to 2004

\begin{tabular}{|l|l|c|}
\hline \multicolumn{1}{|c|}{ Type of Legitimacy } & \multicolumn{1}{|c|}{ Arguments } & No. of Citations \\
\hline \multirow{4}{*}{ Moral } & Task Results & 27 \\
\cline { 2 - 3 } & Conformity versus Results & 15 \\
\cline { 2 - 3 } & Modern Technique & 3 \\
\cline { 2 - 3 } & Total & $\mathbf{4 5}$ \\
\hline \multirow{3}{*}{ Cognitive } & Mimetic Isomorphism & 10 \\
\cline { 2 - 3 } & Other arguments & 6 \\
\cline { 2 - 3 } & Total & $\mathbf{1 6}$ \\
\hline Pragmatic & External recognition & 1 \\
\cline { 2 - 3 } & Total & $\mathbf{9}$ \\
\hline
\end{tabular}

Source: research data.

In terms of Moral Legitimacy, what stands out is the argument of Task Results, which is proof of a strategy of divulging results of program assessments in 2001 and 2002, utilizing mainly the discourse of the COA in the radio program The Voice of Brazil and the Government Information Sheet.

The argument of Conformity versus Results in its turn shows the complementary nature between the controls of conformity and results, with the latter being operational auditing and the consequent need for action by the COA on two levels. There also emerges an attempt to link the control of results to the 
reform movement of the State which took place in this period. Resorting to the content of the interviews, there is a larger number of quotations (43) for the same code which, analyzed, denotes a dichotomy that exists between these two types of control carried out by the Court.

While an internal train of thought at the COA defends operational auditing as a very important activity for the control of results, another believes that owing to the level of corruption in the country, the control of legality, which is seen in the judgment of accounts and audits of conformity, must be predominant. The belief that operational auditing is unimportant is closely linked to the name of the COA. The word Court conjures up a certain image and values connected with making judgments, associated with judiciary power. The word Audits gives the impression that the main function of the organization is to judge the accounts of public administrators.

In an extreme situation, the success of operational auditing, a characteristic of an Anglo-Saxon control model for financial controllers and general auditors, would pose a threat to the model of the court of audits. Nevertheless, a possible tendency is an approaching of the two models, that of controller and that of a court of audits, with the preservation of the most interesting characteristics of each: processing of information by auditors on the one hand and the exercise of power of judgment on the other. The discussion over the two types of control, or even the eventual criticisms of operational auditing does not exist in the official discourse of the organization and is little seen in official documents. The activity is not openly criticized, but nor is any action being taken to effectively expand it.

Another question that impacts the legitimacy of operational auditing, closely related to the dichotomy between conformity control and control of results, is the issuing of recommendations at the end of tasks instead of determinations. The latter, being proper for conformity auditing, are of a coercive nature for public managers, who can be fined by the Court for not adopting the respective arrangement. The concept of recommendation, in its turn, arose during the discussion of the earliest operational auditing tasks in answer to questions raised concerning how to direct to the audited bodies suggestions with a view to eliminating detected flaws. The thesis that prevailed up to the time of writing has been that, in the tasks of operational auditing, owing to the lack of legal basis for the issuing of determinations for the correction of the problems found, the COA should issue recommendations whose adoption by part of those audited are optional and also as a way for the Court not to interfere in the discretion of the public administrator or interfere in his management.

Therefore, a significant objection that is shown is that the recommendations are 
a reflection of a very low level of effectiveness in comparison with the determinations. Contrary to the other questions that do not explicitly appear in official documents or events, the opinion of a then Minister and former President of the COA has been registered in a lecture delivered in 1999 against operational auditing due to this fact.

The people interviewed also question the legitimacy of operational auditing because they do not foresee effective results from the recommendations of these types of tasks, mainly in comparison to other types of task carried out by the COA such as audits carried out on public work projects or the concession of public services, where the determinations of the Court would have the weight of a type of power that other HIBs do not possess but would like to.

When it comes to Cognitive Legitimacy, the argument of Mimetic Isomorphism mainly uses the United Kingdom as a reference for using operational auditing as an indispensable activity of the Court, with references to the need to adapt the techniques of that country to our reality. There are also references to other arguments related to different learning processes that can be considered pertinent to the typology of this sort of legitimacy.

One point that the interviewees highlighted is the difference between the environment in which operational auditing is done in countries from which it was imported and how it is done in Brazil. According to the interviewees, in the USA, Canada and the UK, parliament is the one to effectively carry out the inspection of the deployment of public resources and administrative continuity is greater, there are performance indicators and far more statistics available. There is also greater demand concerning government actions and the results are more valued, being the object of news on prime time newscasts, which are all a far cry from the reality of our country.

Pragmatic Legitimacy, corresponding to the External Recognition argument, translated different types of manifestations from external actors favorable to operational auditing. The same argument identified in the interviews suggests that, whereas there in an internal debate between the two lines of thinking, shown in operational auditing versus conformity auditing, externally, there are not criticisms in relation to the former. Conversely, according to the interviews and documental examination, managers who have already been audited would have a very favorable opinion of the tasks.

Operational auditing tasks would be well accepted because they supply information about performance, efficiency and the efficacy of government programs and managers which means that to begin they do not have this information. The operational auditing task itself draws attention to the program, 
divulging its shortcomings in order to increase the chances that they will be solved.

Finally, the COA strategy, by seeking to act in conjunction with government managers would also contribute to better external acceptance of the activity. In this case, the actions of the organization would be similar to that of a consultancy. The strategy used in the assessment of programs therefore seems to confer pragmatic legitimacy to government organs whose programs are the object of analysis, bearing in mind that their main concern would be helping managers to improve the results of their programs. In their turn, the critics of operational auditing speculate that the good reception of operational auditing by managers is due to the fact that the Court, while it is doing operational auditing, does not play its traditional role in the search for irregularities.

\section{Institutionalization of Operational Auditing at the Court OF AUdiTORS}

In short, it can be confirmed that if on the one hand the strategy of the organization confers pragmatic legitimacy to one part of the tasks and there are mimetic and coercive isomorphic factors which confer cognitive legitimacy to the activity, on the other hand questions persist that prevent the activity from attaining moral legitimacy at all levels of the organization. The result of this process appears to be the continuity of the operational auditing activity with resources that are by far inferior to the other conformity control activities carried out by the COA. Asked whether the Court should continue to carry out operational audits, all those interviewed said yet, but point out that in some cases the volume of resources should be less than those allocated to the other activities of the COA for the control of legality.

Figure 2 shows the relationship between the different types of legitimacy, the isomorphic phenomenon and the institutionalization of the operational auditing activity at the COA. We can see the occurrence of mimetic isomorphism, acting as a source of cognitive legitimacy. The explicit constitutional attribution of the competence to carry out operational auditing, in turn, acted to establish a coercive mechanism, also leading to cognitive legitimacy. 


\section{Figure 2: Operational Auditing at the Court of Auditors - Legitimacy and Institutionalization}

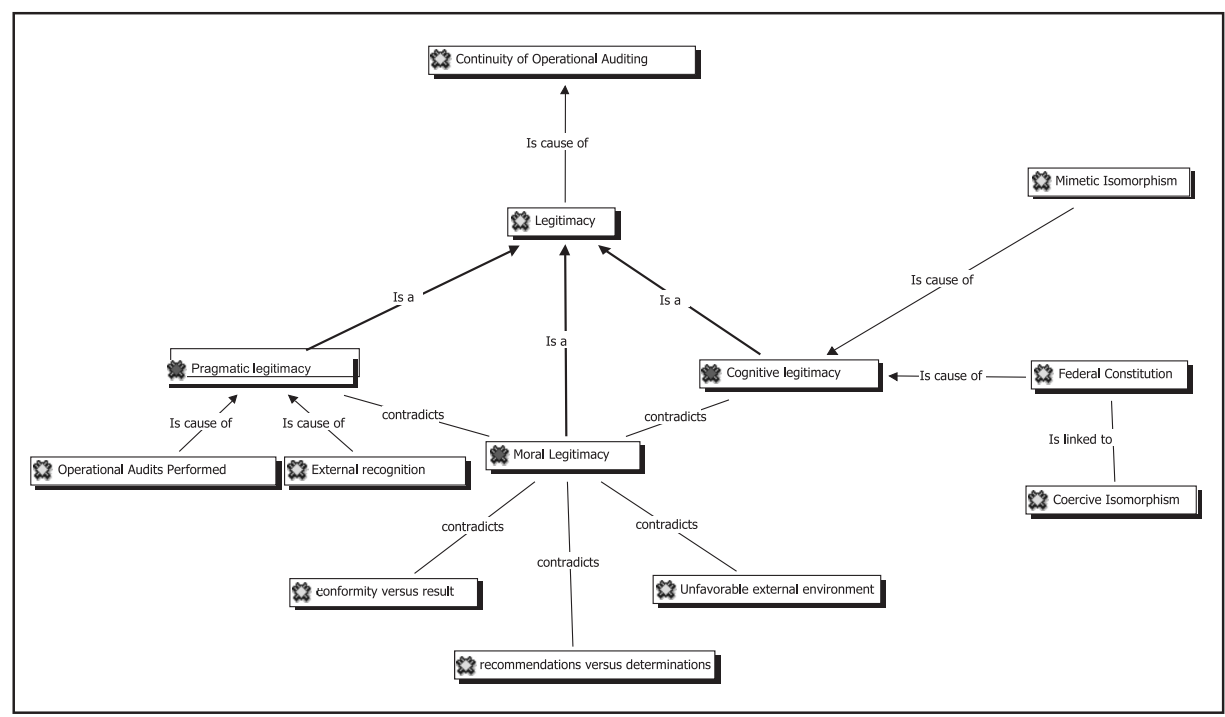

Source: research data.

Cognitive legitimacy, in some cases, is on the same level as moral legitimacy, which acts contrary to the development of operational auditing. Factors related to the Brazilian political-institutional environment, the peculiarities of operational auditing and the dichotomy between the control of results and legality act in the field of moral legitimacy unfavorably to institutionalization of the activity at the COA. Finally, pragmatic legitimacy, originating from the external knowledge of the tasks carried out is aligned with cognitive legitimacy in the sense of continuity of the operational auditing at the COA, which is nothing more than its institutionalization.

With the observation of the phenomenon of the introduction of the activity of operational auditing at the COA under the light of the institutionalization model of Tolbert and Zucker (1997), the presence of three sequential processes was detected (habitualization, objectification and sedimentation), albeit replicated in two of the periods that were analyzed.

In the first period (1987-1992), which corresponds to the introduction of operational auditing by the organization, the mimetic processes that resulted from the first pilot schemes and the adoption of new structures correspond to the Habitualization process. The intense discussion process and the publication of texts promoted by defenders of this new modality of auditing which resulted from it, in the constitutional attribution of the competence to carry out tasks of this 
nature, are the characteristics of the Objectification process. Finally, the diffusion of the practice through training programs at all units of the Court, which went on to carry out operational auditing tasks routinely, the resistance by groups against the defense of groups who believed in the practice corresponds to the Sedimentation process.

Likewise, in the second half of the second period analyzed (1993-1998) and in the third period (1999-2004) we noted the repetition of this cycle in relation to a particular type of operational auditing, directed to the analysis of public programs. Once again, mimetic processes occurred that resulted in pilot programs and new structures for evaluating programs corresponding to the Habitualization process. We also noted a new stage of theorization and monitoring of program evaluation at other HIBs in other countries, with the active presence of defenders of the modality, characterizing an Objectification process. The creation and maintenance of the new structures up to 2004 denote a new Sedimentation process.

Thus, we can confirm the cyclic character, or spiral, of the institutionalization process observed by Medeiros (2004), in which the processes that begin and lead to institutionalization of an activity are repeated over time, leading to changes in the way the activity is structured. Therefore, even though the sequential processes of the model of Tolbert and Zucker (1997) can be utilized for the analysis of an institutionalization process, the stages of pre, semi and full institutionalization proposed in that model would have to be viewed with caution. In the case of the analysis, according to the model of these authors, the activity of operational auditing at the COA would have reached the stage of full institutionalization on two occasions.

The circular nature of the institutionalization process may equally be seen when analyzing the dynamic of the evolution of the activity of operational auditing at the COA using the typical pattern of events of institutionalization shown by Lawrence and Jennings (2001). Over the period that was analyzed, a cycle of innovation, diffusion, formation of legitimacy and deinstitutionalization was detected when the operational auditing activity was initially introduced (1987), followed by another of innovation, diffusion, formation of legitimacy, with the Training Project for the Evaluation of Public Programs (1996) and, finally, another of innovation, diffusion, formation of legitimacy from the implementation of the Cooperation Project with the United Kingdom (1998). This behavior confirms the position of Lawrence and Jennings (2001), who admit that deinstitutionalization can occur in short periods in a process of dominant stability interrupted by occasional volatility. 
Thus, the institutionalization process appears to begin with a phase of innovation, which shares many of the characteristics of the habitualization phase of Tolbert and Zucker (1997), followed by a phase of diffusion, which is also similar to the objectification stage of these authors. Nevertheless, the following phase could be partial saturation, in which the structures, processes and resources involved are found, but not spread throughout the entire group. In this phase, several factors that are not analyzed in this study may lead the activity to stagnation and deterioration, which characterize partial deinstitutionalization. Without its total reversion, i.e., the disappearance of the institution, a new flow of innovation modifies the structures in place up to that time, leading to a fresh intensification of the process. Legitimacy, which is closely linked to institutionalization, is always found to be present to a greater or lesser degree in all phases, increasing with a higher degree of institutionalization and decreasing with deinstitutionalization.

We see that mimetic isomorphism was a determining factor in the three phases analyzed in this study, since the operational auditing initially sought patterns that were in place in Canada, later in the United States and finally in the United Kingdom. In its turn, coercive isomorphism seems to be linked to the stability of the activity in the organization, in the form of the competence conferred upon the COA by the Federal Constitution of 1988. There is no discussion as to whether the Court must carry out operational audits, the debate being restricted to the intensity of the effort dedicated to this activity.

In terms of behavior of the legitimacy variable, it can be seen that only when cognitive legitimacy and moral legitimacy are aligned are there expansion cycles of operational auditing at the COA. However, it was not possible to link the behavior of any of the types of legitimacy utilized in this study to the phase of deinstitutionalization, in which the operational auditing tended to lean towards formalism, being done in the same way as other auditing tasks carried out by the court.

Therefore, the behavior of the institutionalization process could be shown according to the model in Figure 3 below. 


\section{Figure 3: Institutionalization Process in a Circular Perspective}

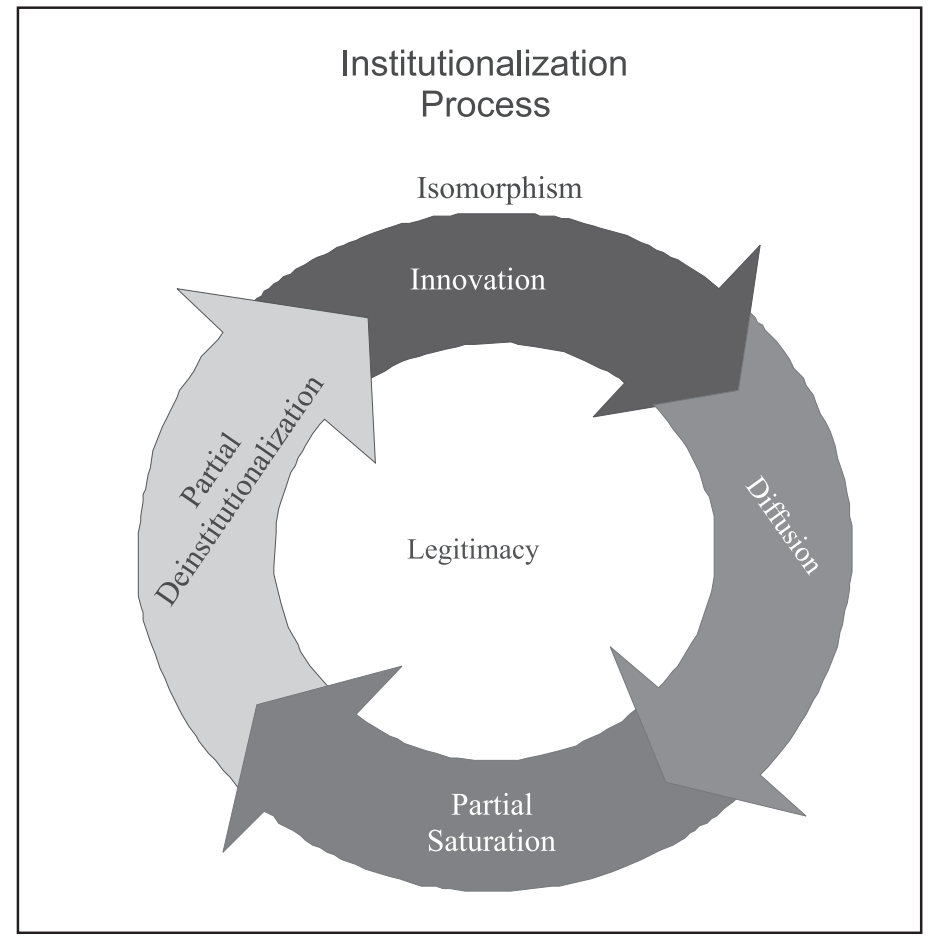

\section{Conclusions}

The results of this study suggest that the concepts of isomorphism and legitimacy are related. The beginning of operational auditing at the $\mathrm{COA}$ is linked to a mimetic isomorphism process in relation to other Higher Inspection Bodies in that the legitimacy variable makes this process possible. Thus, isomorphism and legitimacy would be the cause of the initial influx of resources and the creation of a structure for carrying out operational auditing and maintenance of internal and external training processes that retrofeed the cycle of the activity.

From the first period analyzed, 1987 to 1992, we saw that certain questions, on the moral legitimacy plane, appeared as counter-arguments to the motives used for the introduction of the activity at the COA. One example of this is the difference between the political-institutional environment in Brazil and countries in which operational auditing is widely used, which would be less corrupt and with greater and more pervious administrative continuity, the typical recommendations of this 
kind of work. In the Brazilian political environment, where these characteristics are inverse, the impossibility of issuing coercive determinations in work that evaluates results would greatly weaken the adoption of measures to correct faults. They seem thus, with variables pertaining to the culture and institutional environment, different in Anglo-Saxon countries. These issues created a divide in the analyzed organization: on the one hand, those favorable to operational auditing activities and on the other those who were skeptic about the results of this activity in Brazil.

Therefore, the phenomenon of isomorphism is related only to the field of cognitive legitimacy, favoring the institutionalization of operational auditing at the Court of Auditors. Factors connected to culture and the institutional environment of the country, however, interfere in the dimension of moral legitimacy, resulting in the institutionalization of the activity on a secondary level in the analyzed organization.

\section{Artigo recebido em 21.02.2006. Aprovado em 30.05.2006.}

\section{References}

Araújo, I. P. S. A. (2001).

Introdução à auditoria operacional. Rio de Janeiro: Editora FGV.

Barros, E. F. (1999).

Auditoria de desempenho nos tribunais de contas estaduais brasileiros: uma pesquisa exploratória. Master's degree dissertation, Faculdade de Economia, Administração e Contabilidade. Universidade de São Paulo, SP, Brasil.

Berger, P. L., \&

Luckmann, T. (2003).

A construção social da realidade: tratado de sociologia do conhecimento. Petrópolis: Editora Vozes.

Dimaggio, P. J., \&

Powell, W. W. (1991).

The iron cage revisited: institutional isomorphism and collective rationality in organizational fields. In W. W. Powell \& P. J. DiMaggio (Eds.). The new institutionalism in organizational analysis. Chicago: The University of Chicago Press.

Hannan, M. T., \&

Freeman, J. (1977).

The population ecology of organizations. American Journal of Sociology, 82(5), 929-964.

International Organization of Supreme Audit Institutions - INTOSAI (1995).

Normas de Auditoria da Intosai. (Tribunal de Contas da União, Trans.). Salvador: Tribunal de Contas do Estado da Bahia. (Original work published 1989). 
Jepperson, R. (1991). Institutions, institutional effects and institutionalism. In W. W. Powell \& P. J. DiMaggio (Eds.). The new institutionalism in organizational analysis. Chigaco: University of Chigaco Press.

Lawrence, T. B.,

Winn, M. I., \&

Jennings, P. D. (2001).

The temporal dynamics of institutionalization. The Academy of Management of Review, 26(4), 624644.

Lonsdale, J. (2000).

Developments in value-for-money audit methods: impacts and implications (Vol. 66, pp.73-89). London: International Review of Administrative Sciences.

Machado-da-Silva, C. L., \&

Fonseca, V. (1993).

Homogeneização e diversidade organizacional: uma visão integrativa. Anais do encontro Nacional dos Programas de Pós-graduação em Administração, Salvador, BA, Brasil, 17.

Machado-da-Silva, C. L.,

Fonseca, V. S. da., \&

Fernandes, B. H. (2000).

Cognição e Institucionalização na Dinâmica da Mudança em Organizações. In S. B. Rodrigues \& M. P. Cunha (Orgs.). Estudos organizacionais: novas perspectivas na administração de empresas - uma coletânea Luso-Brasileira. São Paulo: Iglu.
Machado-da-Silva, C. L.,

Guarido Filho, E. R.,

Nascimento, M. R., \&

Oliveira, P. T. (2003).

Institucionalização da mudança na sociedade brasileira: o papel do formalismo. In M. M. F. Vieira \& C. A. Carvalho (Orgs.). Organizações, instituições e poder no Brasil. Rio de Janeiro: FGV.

Medeiros, P. H. R. (2004).

Governo eletrônico no Brasil: aspectos institucionais e relações com governança. Master's degree dissertation, Faculdade de Economia, Administração, Contabilidade e Ciência da Informação e Documentação. Universidade de Brasília, DF, Brasil.

Meyer, J., \&

Rowan, B. (1991).

Institutionalized organizations: formal structure as myth and ceremony. In W. W. Powell \& P. J. DiMaggio (Eds.). The new institutionalism in organizational analysis. Chicago: The University of Chicago Press.

Pacheco, F. L. (2002).

$\mathrm{O}$ isomorfismo institucional nos teatros da região metropolitana do Recife. In Anais do encontro Nacional dos Programas de Pós-graduação em Administração, Salvador, BA, Brasil, 26.

Pfeffer, J., \&

Salancik, G. R. (1978).

The external control of organizations: a resource dependence perspective. New York: Harpes \& Row. 
Pollitt, C., \&

Bouckaert, G. (2000).

Public management reform. Oxford: Oxford Univesity Press.

Powell, W. W. (1991).

Expanding the scope of institutional analysis. In W. W. Powell \& P. J. DiMaggio (Eds.). The new institutionalism in organizational analysis. Chicago: The University of Chicago Press.

Scott, W. R. (1991).

Unpacking institutional arguments. In W. W. Powell \& P. J. DiMaggio (Eds.). The new institutionalism in organizational analysis. Chicago: The University of Chicago Press.

Scott, W. R. (1994).

Institutions and organizations: toward a theoretical synthesis. In W. R. Scott \& J. Meyer (Orgs.). Institutional environments and organizations: structural complexity and individualism. Thousand Oaks: Sage.

Scott, W. R. (1995).

Organizations, rational, natural and open systems (4th ed.). New Jersey: Prentice Hall.
Scott, W. R. (2001).

Institutions and organizations (2nd ed.). Thousand Oaks: Sage Publications

Suchman, M. C. (1995).

Managing legitimacy: strategic and institutional approaches. Academy Management Review, 20(3), 571-560.

Tolbert, P. S., \& Zucker, L. G. (1997).

The institutionalization of institutional theory. In S. Clegg, C. Hardy, \& W. Nord (Orgs.). The Handbook of Organization Studies. London: Sage Publications Ltd.

Vieira, M. M. F. (2004).

Por uma boa pesquisa (qualitativa) em administração. In M. M. F. Vieira \& D. M. Zouain (Orgs.). Pesquisa qualitativa em administração. Rio de Janeiro: Editora FGV.

Yin, R. K. (2001).

Estudo de caso: planejamento e métodos. Porto Alegre: Bookman.

Zucker, L. G. (1991).

The role of institucionalization in cultural persistance. In W. W. Powell \& P. J. DiMaggio (Eds.). The new institutionalism in organizational analysis. Chicago: The University of Chicago Press. 